\title{
Constructs Related to Community College Student Satisfaction in Blended Learning
}

\author{
Stephen D. Sorden \\ Chinle Unified School District, \\ Chinle, Arizona, USA \\ steve@sorden.com
}

\author{
Ishmael I. Munene \\ Northern Arizona University, \\ Flagstaff, Arizona, USA
}

Ishmael.Munene@nau.edu

\section{Executive Summary}

This paper discusses the constructs of social presence, collaborative learning, computer-supported collaborative learning, and satisfaction in blended learning environments. It presents the results of a study that used the Collaborative Learning, Social Presence, and Satisfaction (CLSS) questionnaire, which was conducted on one campus in a multi-campus community college system. The CLSS questionnaire measured the amount of perceived collaborative learning, perceived social presence, and reported satisfaction in a blended course. The sample of participants was drawn from students enrolled in one or more blended courses on one campus in a multi-campus, community-college system in the southwestern United States.

The study posed four questions, accompanied by four related hypotheses. Does perceived social presence in a blended, community-college course correlate with reported student satisfaction? Does perceived collaborative learning in a blended, community-college course correlate with reported student satisfaction? Does perceived social presence in a blended, community-college course correlate with perceived collaborative learning? How do age, gender, ethnicity, computer expertise, and number of distance courses previously taken correlate with perceived social presence, perceived collaborative learning, and reported course satisfaction in a blended, communitycollege course?

The data analysis consisted mainly of a descriptive analysis and correlational analysis using the Pearson Product Moment Correlation Coefficient (Pearson's r). In addition, a Mann Whitney U test was run separately on the nominal variables for Caucasian and Latino ethnicity, which found a significant, higher perception of social presence for the Latino participants. The descriptive analysis showed that the sample roughly mirrored the general population of the college. The correlational analysis resulted in the rejection of the first three null hypotheses, while the fourth was retained. The study found a moderate, positive relationship between social presence and student

Material published as part of this publication, either on-line or in print, is copyrighted by the Informing Science Institute. Permission to make digital or paper copy of part or all of these works for personal or classroom use is granted without fee provided that the copies are not made or distributed for profit or commercial advantage AND that copies 1) bear this notice in full and 2) give the full citation on the first page. It is permissible to abstract these works so long as credit is given. To copy in all other cases or to republish or to post on a server or to redistribute to lists requires specific permission and payment of a fee. Contact Publisher@InformingScience.org to request redistribution permission. satisfaction, and the constructs of perceived collaboration and student satisfaction appeared to be highly related. The study also confirmed that there appears to be a link between rising levels of perceived collaboration and rising levels of perceived social presence. With the exception of a relationship between Latinos and higher self-reported perceptions of social presence, the study did not find a significant correlation be- 
tween any of the demographic variables and the three constructs that were measured. While there is as yet no strong evidence, this may be the first study to suggest a higher relationship between Latinos/Hispanics and perceived social presence in blended learning.

One major conclusion that can be drawn from this study is to confirm that there does indeed appear to be a strong link between the amount of social presence and collaborative activities that a student perceives in a blended course and that student's self-reported satisfaction in the course. This study suggests that blended learning featuring collaboration and social presence can help institutions create better programs and support services that may lead to more effective learning environments. The authors conclude with a discussion of the result implications for education and blended learning, and they make recommendations for future research.

Keywords: collaboration, collaborative learning, social presence, student satisfaction, blended learning, hybrid course

\section{Introduction}

In order to attract and retain students, institutions and educators must continue to look for innovative ways to meet evolving student learning needs. Blended learning may represent one such educational innovation. Students in blended-learning environments have reported increased satisfaction with the blended model over either face-to-face or online learning environments, even though, according to Clusky, Hodges, and Smith (2006), learning effectiveness appears to be roughly equal. Albrecht (2006) also reports increased student satisfaction with blended learning. Means, Toyama, Murphy, Bakia, and Jones (2009) found that blended instruction was generally more effective when various forms of blended learning were compared with conventional face-toface classes. After controlling for the instructor, exams, and number of students, Cluskey et al. (2006) found significantly improved student performance and course-pass rates after transitioning from a traditional face-to-face (f2 $\mathrm{f}$ ) course to a hybrid online accounting class. Martin and Trigwell (2005) have attributed this advantage to variation theory which explains the increase in learning as resulting from the blending of instructional approaches.

This study explored how the three constructs of social presence, collaborative learning, and student satisfaction correlate to each other in blended-learning environments. While the topics of social presence and collaborative learning have been studied in online education (Gunawardena \& Zittle, 1997; So \& Brush, 2008), little research has been done on how collaborative learning and social presence affect student satisfaction in a blended-learning environment, especially at the community-college level. If it can be demonstrated that there is a positive correlation in a blended course between collaborative-learning activities and social presence with student course satisfaction, then it would merit continuing to focus on approaches that strengthen these constructs in a blended, community-college environment.

\section{Social Presence}

Social presence helps learners to project themselves online and feel a sense of community. Garrison (2009) further suggested that social presence occurs when learners are able to identify with a community, communicate within that community, and develop relationships by projecting their personalities. Social presence has been well-documented as an important construct in online learning environments (Gunawardena, 1995; Gunawardena \& Zittle, 1997; Liu, Gomez, Khan, \& Yen, 2007; Richardson \& Swan, 2003; Tu, 2002; Tu \& McIsaac, 2002). Tu (1999) stated that social presence is a significant factor in distance education and that it is one of the most important factors for social learning in computer-mediated environments. A general finding from this body of research is that when information is presented in a manner that increases the perception of social presence, the learner becomes more engaged and retains the information better (Homer, 
Plass, \& Blake, 2008; Richardson \& Swan, 2003). Liu, Gomez, and Yen (2009) found that social presence is also a predictor of course retention and the final grade in online environments at community colleges, and they recommend two specific actions: early identification and effective intervention.

There is a strong correlation between social presence and student satisfaction (Gunawardena, 1995; Gunawardena \& Zittle, 1997; Richardson \& Swan, 2003). Both Rourke, Anderson, Garrison, and Archer (2001) and Rovai (2002) stated that this correlation is important in the development of a community of learners. So and Brush (2008) found that student perception of social presence correlates to perception of collaborative learning and overall satisfaction. Weinel, Bannert, Zumbach, Malzahn, and Hoppe (2011) found that while social presence does not cause collaboration, it can affect the attitude of participants towards collaborating on a particular task.

Other researchers have also found a connection between social presence and blended learning (Jusoff \& Khodabandelou, 2009; Kang \& Kang, 2008; So \& Brush, 2008). Because a blended course may have both online and face-to-face activities, identifying the cause of social presence becomes a little more complicated. Does the social presence result from the face-to-face meetings, or does it develop because of interactive online activities?

\section{Collaborative Learning}

Collaborative learning occurs when learners interact to construct common meaning and knowledge. The importance of learning through social interaction and collaboration has been confirmed repeatedly (Bandura, 1985; Roschelle, 1992; Tu \& Corry, 2003; Wenger, 1999). Tu (2004) stated that it is an essential component for creating online learning communities.

Roschelle (1992) argued that the main point of collaboration is convergence, or the mutual creation of understanding and knowledge. Jeong \& Chi (2007) later confirmed Roschelle's findings that knowledge convergence did occur during collaborative learning. Recently, researchers such as Jarvela and Jarvenoja (2011) are beginning to explore how individuals can direct their own learning within a social-learning environment while simultaneously affecting and being affected by that environment.

Several studies have linked increased satisfaction in an online course to increased collaboration (Ferguson \& DeFelice, 2010). Jung, Choi, Lim, and Leem (2002) found that students who reported a high level of collaboration with others in the course also expressed a higher level of satisfaction than those who engaged solely in task-oriented interaction with the instructor. Nummenmaa and Nummenmaa (2008) found that those who interacted collaboratively had a more positive reaction to a course.

\section{Computer-Supported Collaborative Learning}

While collaborative learning should be a strong component of both online and face-to-face environments, computer-supported collaborative learning (CSLC) has emerged as a separate field of research (Resta \& Laferriere, 2007). CSLC is concerned with how we interactively learn together using computer-mediated communication (Stahl, Koschmann, \& Suthers, 2006), and it is characterized by the sharing and construction of knowledge among participants using synchronous or asynchronous communication as their primary means of communication. CSCL research adds a rich dimension of understanding and effective practices to blended learning.

As technology becomes more user-friendly, the division between face-to-face and online environments will likely fade, and the technology will cease to be the demarcation in blended learning (Osguthorpe \& Graham, 2003). Dommel (2005) introduced a concept known as ambient collaboration where computer technology is no longer central to online collaboration. Instead, the tech- 
nology sits unobtrusively in the background, allowing users to synergistically move between face-to-face and virtual workspaces, concentrating on presence and collaboration rather than on tools or the technology. As our understanding of blended theory develops, the idea of blending may be more about collaborative learning and individual reflection than a blending of technology or location (Garrison \& Vaughan, 2007).

\section{Satisfaction in Blended-Learning Environments}

A major goal of a learning-centered strategy should be student satisfaction with the learning experience. If students feel that they have learned the material - that they have a deep understanding of it - and that the learning experience was positive, then they will have a strong sense of satisfaction at the end of the course (Martin \& Reigeluth, 1999). Satisfaction is an affective construct that is often considered to be a predictor of learning outcomes (LaPointe \& Gunawardena, 2004). Stein (2004) found that satisfaction is determined by the degree of structure in the course. Elements that defined structure include clearly defined objectives, assignments, and deadlines.

Richardson and Swan (2003) studied learners' perceived social presence and its relationship to perceived learning and satisfaction with instructors. They found that all the variables correlated and that social presence was a good predictor of student satisfaction. Beyond being important from the learner's perspective, student satisfaction is important to the institution because it has been shown to be an important factor in student retention (Liu et al., 2007; Liu et al., 2009).

\section{Research Questions and Hypotheses}

This study examined the relationships between perceived collaborative learning and social presence with student satisfaction in blended courses on one campus in a community-college system. The following research questions and hypotheses were posed:

1. Question 1: Does perceived social presence in a blended, community-college course correlate with reported student satisfaction?

Hypothesis 1 (H1): There will be no significant correlation between the constructs of perceived social presence and reported course satisfaction as measured by the Collaborative Learning, Social Presence, and Satisfaction (CLSS) Questionnaire in a blended course at one community college campus.

2. Question 2: Does perceived collaborative learning in a blended, community-college course correlate with reported student satisfaction?

Hypothesis 2 (H2): There will be no significant correlation between the constructs of perceived collaborative learning and reported course satisfaction as measured by the Collaborative Learning, Social Presence, and Satisfaction (CLSS) Questionnaire in a blended course at one community college campus.

3. Question 3: Does perceived social presence in a blended, community-college course correlate with perceived collaborative learning?

Hypothesis 3 (H3): There will be no significant correlation between the constructs of perceived social presence and perceived collaborative learning as measured by the Collaborative Learning, Social Presence, and Satisfaction (CLSS) Questionnaire in a blended course at one community college campus.

4. Question 4: How do age, gender, ethnicity, computer expertise, and number of distance courses previously taken correlate with perceived social presence, perceived collaborative learning, and reported course satisfaction in a blended, community-college course? 
Hypothesis 4 (H4): There will be no significant correlation between student demographic data (gender, age, ethnicity, computer expertise, and number of distance courses previously taken) and the constructs of perceived social presence, perceived collaborative learning, and reported course satisfaction as measured by the Collaborative Learning, Social Presence, and Satisfaction (CLSS) Questionnaire at one community college campus.

\section{Study Design}

This study used a quantitative correlational design that allowed for the analysis of student demographic data and the relationships between the two independent variables (social presence and collaboration) and a dependent variable (student satisfaction) in a blended course. This design was selected because of its robustness in the analysis of several variables in a single study as well as its ability to determine the strength of any significant relationships between the variables.

\section{Population and Sample}

The sample of participants was drawn from students enrolled in one or more blended courses on one campus in a multi-campus, community-college system in the southwestern United States. Students in the sample were not randomly selected; rather, they were part of a canvass sample in the spring of 2011 that invited all blended classes at one campus to participate in the study. Most courses at this campus were not blended, but 12 blended courses were identified. Of these 12, one course was treated as a pilot course. The researchers received permission to access the remaining 11 courses for approximately 30 minutes to request voluntary participation, and all blended courses were included in the study.

Ultimately, a sample size of 108 participants was achieved, which yielded a confidence interval of 6.95 with a confidence level of $95 \%$. The response rates ranged from a low of $33 \%$ to $100 \%$, with an overall average of $77 \%$, or 108 students out of a possible 140 . The sample consisted of $71 \%$ Caucasian and $15 \%$ Latino, with exactly half of the participants being 25 years old or younger, and half being 26 years old or older.

\section{Instrumentation/Sources of Information}

The instrument used in this study, the Collaborative Learning, Social Presence, and Satisfaction (CLSS) Questionnaire, measures perceived collaboration, social presence, and satisfaction (So \& Brush, 2008). The questionnaire has four sections: demographics, satisfaction, collaborative learning, and social presence. As addressed by So and Brush (2008, p. 324), the validity of the instrument was tested by using an exploratory factor analysis.

A small pilot group of five students in one course answered the questionnaire before it was administered to students in the other eleven blended courses. As a result of this pilot, one ambiguous question was slightly altered for clarity. In addition, a committee of experts, consisting of three colleagues, was consulted to determine if any ambiguous questions or other issues existed with the questionnaire. Other than the one question that had to be slightly rewritten as a result of the pilot, no questions were determined to be ambiguous, and none were removed from the original questionnaire developed by So and Brush (2008).

\section{Data Analysis}

Data analysis took place in four steps: data screening, tests for normality, descriptive statistics of the sample, and a correlational analysis. After reviewing each of the 108 questionnaires by hand, six questionnaires were discarded because they were assessed to not have honest response patterns. Three more questionnaires were discarded for not being complete and having excessive missing data. 
The mean was calculated for each section in each record and saved as satisfaction, collaboration, and social presence. The $\mathrm{z}$ scores were calculated on each of those means; we looked for z-scores beyond plus or minus 3.29. After reviewing the $\mathrm{z}$ scores, one additional questionnaire was eliminated because it had an unacceptably low $\mathrm{z}$ score (-3.57) in the social-presence section. The datascreening process left a final total of 98 questionnaires (from the original 108) for subsequent data analysis.

Before looking at the descriptive statistics of the demographic variables, a descriptive analysis for normality was performed on the section mean scores. Tests included an analysis for skewness and kurtosis, the Kolmogorov-Smirnov goodness-of-fit test, the Shapiro-Wilk test for normality with the standard alpha of .05, and a visual inspection of Q-Q plots to provide adequate evidence that the distributions approximated normality. Based on this analysis and the calculated indicators of normality, we determined that the variables sufficiently approximated normality and that we could continue with an analysis of the descriptive statistics for the demographic variables as well as with the correlational analysis.

Around $62 \%$ (61) of the respondents were female while about $38 \%$ (37) were male. This suggests that the students taking blended courses did not differ in makeup from the general population of the college as reported in the latest statistics provided by the college's department for planning and institutional research. In other words, the gender of the participants reflected the overall campus population.

Two interesting characteristics surfaced from the statistic on age. One was the large number of older students ( 45 years old or older) who were taking a blended course ( $16 \%$ or 16 participants), and the second was that the sample was almost evenly divided between traditional students 25 years old or younger ( $46 \%$ or 45 participants) and nontraditional students who were 26 years old or older ( $54 \%$ or 55 participants).

Table 1 discloses data about the ethnicity of the participants. As with the other demographic information, the breakdown of ethnicity mirrored the overall population of the college. Caucasians and Latinos were the largest ethnic groups, comprising $72 \%$ (71 participants) and $14 \%$ (14 participants), respectively. About 6\% (6) of the participants identified themselves as "other." This could be accounted for by the fact that there was no category for Native American, and there are several Native American reservations near the college campus. One possible flaw in the study may have been to allow a category for "Not Applicable," which may not have been an appropriate category to self-report for ethnicity. This value was kept in the results, however, and reported.

Table 1

Self-Reported Ethnicity of Participants

\begin{tabular}{lcc}
\hline Ethnicity & Frequency & Percent \\
\hline African American & 1 & 1.0 \\
Asian/Pacific Islander & 4 & 4.1 \\
Caucasian & 71 & 72.4 \\
Latino & 14 & 14.3 \\
Other & 6 & 6.1 \\
Not Applicable & 2 & 2.0 \\
Total & 98 & 100.0 \\
\hline
\end{tabular}

Participants were asked to estimate their level of experience with computers. The number of participants identifying themselves at either extreme was nearly evenly divided - eighteen percent (18) of participants said they were novice; sixteen percent (16) of participants said they were expert. A surprisingly large number of the participants placed themselves in the middle: Sixty four 
percent (63 participants) reported that they had an intermediate amount of experience with computers. It would warrant additional research to try to determine if this statistic mirrors the general college population or whether students with an intermediate or expert amount of experience were more likely to take blended courses.

In terms of distance-education courses taken prior to enrolling in the current blended course, most of the participants - 60\% (59 individuals) - had only taken one or no distance- education courses prior to enrolling in the current blended course. Around 45\% (29 participants) had taken three or more such classes.

\section{Findings}

\section{Questionnaire Statements by Ranked Mean}

To provide a good overview of the questionnaire, all statements from the questionnaire are reported in Tables 2, 3, and 4. They are ranked from the highest mean to the lowest mean as reported by the 98 participants in Likert-type scales where a " 5 " means "strongly agree." It is worth noting that the statement that reported the lowest mean was related to whether collaborative activities were better in an online environment than in a face-to-face environment. This seems to indicate that students feel that collaboration is better when it occurs in a face-to-face situation.

Table 2: (CLSS) Questionnaire Items from Satisfaction Section, Listed by Mean from

Highest to Lowest as they were rated by Study Participants

\begin{tabular}{|c|c|c|c|}
\hline Item Description & $\mathrm{N}$ & Mean & SD \\
\hline $\begin{array}{l}\text { 1. Overall, the instructor for this course met my } \\
\text { leaming expectations. (Satisfaction, \#10) }\end{array}$ & 98 & 4.50 & .790 \\
\hline $\begin{array}{l}\text { 2. Overall, this course met my leaming expectations. } \\
\text { (Satisfaction, \#11) }\end{array}$ & 98 & 4.29 & .885 \\
\hline $\begin{array}{l}\text { 3. This course was a useful learning experience. } \\
\text { (Satisfaction, \#5) }\end{array}$ & 98 & 4.20 & .952 \\
\hline $\begin{array}{l}\text { 4. Overall, the leaming activities and assignments of } \\
\text { this course met my leaming expectations. } \\
\text { (Satisfaction, \#9) }\end{array}$ & 98 & 4.13 & .991 \\
\hline $\begin{array}{l}\text { 5. My level of leaming that took place in this course } \\
\text { was of the highest quality. (Satisfaction, } \# 8 \text { ) }\end{array}$ & 98 & 4.04 & .930 \\
\hline $\begin{array}{l}\text { 6. As a result of my experience with this course, I } \\
\text { would like to take another blended course in the } \\
\text { future. (Satisfaction, \#4) }\end{array}$ & 98 & 3.96 & 1.183 \\
\hline $\begin{array}{l}\text { 7. Discussions assisted me in understanding other } \\
\text { points of view. (Satisfaction, \#3) }\end{array}$ & 98 & 3.96 & 1.015 \\
\hline $\begin{array}{l}\text { 8. The diversity of topics in this course prompted me } \\
\text { to participate in the discussions. (Satisfaction, \#6) }\end{array}$ & 98 & 3.90 & 1.079 \\
\hline $\begin{array}{l}\text { 9. I was stimulated to do additional readings or } \\
\text { research on topics discussed online. (Satisfaction, } \\
\# 2 \text { ) }\end{array}$ & 98 & 3.57 & 1.149 \\
\hline $\begin{array}{l}\text { 10. I was able to leam from online discussions. } \\
\text { (Satisfaction, } \# 1 \text { ) }\end{array}$ & 98 & 3.42 & 1.209 \\
\hline $\begin{array}{l}\text { 11. I put in a great deal of effort to leam the Computer } \\
\text { mediated communication system to participate in } \\
\text { this course. (Satisfaction, } \# 7 \text { ) }\end{array}$ & 98 & 3.34 & 1.218 \\
\hline
\end{tabular}


It is worth noting, as displayed in Table 2, that the highest-ranked statements in the "satisfaction" section, as well as the survey taken as a whole, focused on satisfaction with the instructors and the courses. This suggests that students in the study did like the blended format. Indeed, students ranked the statement "As a result of my experience with this course, I would like to take another blended course in the future" very high. Another point worth noting is that students ranked the statement about learning from discussions relatively low. Since engaging in online discussions is often an important characteristic of blended learning, this is somewhat of concern and warrants further study. Finally, there is an interesting pattern in this set of questions that merits further investigation in a future study: As the mean decreases, the standard deviation generally increases.

Table 3: (CLSS) Questionnaire Items from Collaboration Section, Listed by Mean from Highest to Lowest as they were rated by Study Participants

\begin{tabular}{|c|c|c|c|}
\hline Item Description & $\mathrm{N}$ & Mean & SD \\
\hline $\begin{array}{l}\text { 1. Overall, I am satisfied with my collaborative } \\
\text { learning experience in this course.(Collaboration, } \# 8 \text { ) }\end{array}$ & 98 & 3.96 & 1.083 \\
\hline $\begin{array}{l}\text { 2. Collaborative leaming in my group was effective. } \\
\text { (Collaborative, } \# 6 \text { ) }\end{array}$ & 98 & 3.71 & 1.005 \\
\hline $\begin{array}{l}\text { 3. I actively exchanged my ideas with group members. } \\
\text { (Collaborative, } \# 3 \text { ) }\end{array}$ & 98 & 3.70 & 1.057 \\
\hline $\begin{array}{l}\text { 4. I was able to develop new skills and knowledge } \\
\text { from other members in my group.(Collaborative,4) }\end{array}$ & 98 & 3.68 & 1.080 \\
\hline $\begin{array}{l}\text { 5. I felt part of a learning community in my group. } \\
\text { (Collaborative, } \# 2 \text { ) }\end{array}$ & 98 & 3.67 & 1.063 \\
\hline $\begin{array}{l}\text { 6. I was able to develop problem solving skills through } \\
\text { peer collaboration. (Collaborative, \#5) }\end{array}$ & 98 & 3.60 & 1.062 \\
\hline $\begin{array}{l}\text { 7. Collaborative leaming in my group was time } \\
\text { consuming. (Collaborative, } \# 7 \text { ) }\end{array}$ & 98 & 3.11 & 1.014 \\
\hline $\begin{array}{l}\text { 8. Collaborative leaming experience in the computer } \\
\text { mediated communication environment is better than } \\
\text { in a face-to-face learning environment. } \\
\text { (Collaborative, \#1) }\end{array}$ & 98 & 2.67 & 1.138 \\
\hline
\end{tabular}

*Mean as reported by participants in Likert-type scales where " 5 " means "strongly agree."

In Table 3, the highest-ranked item again reflected general satisfaction with an aspect of the course - in this case, collaboration. However, statements about collaboration were generally ranked lower than statements reflecting satisfaction with the courses. This could be because the collaborative experiences were not satisfactory or possibly didn't take place as much as they could have. It is also important to note that the lowest-ranked item in this section suggests that students prefer collaborating in face-to-face (f2f) environments rather than online, which actually supports the flipped classroom theory that advocates having students watch lectures and learn the material in advance, and then focus on problem solving and collaboration in the classroom. 
Table 4: (CLSS) Questionnaire Items from Social Presence Section, Listed by Mean from

Highest to Lowest as they were rated by Study Participants

\begin{tabular}{|c|c|c|c|}
\hline Item Description & $\mathrm{N}$ & Mean & $\mathrm{SD}$ \\
\hline $\begin{array}{l}\text { 1. CMC messages are social forms of communication. } \\
\text { (Social Presence, \#1) }\end{array}$ & 98 & 3.97 & .724 \\
\hline $\begin{array}{l}\text { 2. Where I access CMC (home, office, computer labs, } \\
\text { public areas, etc.) does not affect my ability/desire to } \\
\text { participate. (Social Presence, \#14) }\end{array}$ & 98 & 3.85 & .923 \\
\hline $\begin{array}{l}\text { 3. Using CMC is a pleasant way to communicate with } \\
\text { others. (Social Presence, \#5) }\end{array}$ & 98 & 3.81 & .938 \\
\hline $\begin{array}{l}\text { 4. I am comfortable participating, even though I am not } \\
\text { familiar with the topics. (Social Presence, \#9) }\end{array}$ & 98 & 3.79 & .933 \\
\hline $\begin{array}{l}\text { 5. The language used to express oneself in online } \\
\text { communication is easily understood. (Social Presence, } \\
\# 8 \text { ) }\end{array}$ & 98 & 3.79 & .815 \\
\hline $\begin{array}{l}\text { 6. The large amounts of CMC messages (numbers of } \\
\text { messages and length of messages) do not inhibit my } \\
\text { ability to communicate. (Social Presence, \#16) }\end{array}$ & 98 & 3.73 & .794 \\
\hline $\begin{array}{l}\text { 7. It is easy to express what I want to communicate } \\
\text { through CMC. (Social Presence, \#7) }\end{array}$ & 98 & 3.71 & 1.025 \\
\hline $\begin{array}{l}\text { 8. CMC allows relationships to be established based upon } \\
\text { sharing and exchanging information. (Social Presence, } \\
\text { \#11) }\end{array}$ & 98 & 3.59 & .929 \\
\hline $\begin{array}{l}\text { 9. CMC is technically reliable (e.g., free of system or } \\
\text { software errors that might compromise the reliability of } \\
\text { your online messages reaching ONLY the target } \\
\text { destination). (Social Presence, \#10) }\end{array}$ & 98 & 3.50 & .987 \\
\hline $\begin{array}{l}\text { 10. The language people use to express themselves in } \\
\text { online communication is stimulating. (Social Presence, } \\
\# 6 \text { ) }\end{array}$ & 98 & 3.48 & .876 \\
\hline $\begin{array}{l}\text { 11. It is unlikely that someone else might redirect your } \\
\text { messages. (Social Presence, \#17) }\end{array}$ & 98 & 3.44 & .953 \\
\hline $\begin{array}{l}\text { 12. CMC messages convey feeling and emotion. (Social } \\
\text { Presence, \#2) }\end{array}$ & 98 & 3.28 & .939 \\
\hline 13. CMC is private/confidential. (Social Presence, \#3) & 98 & 3.26 & 1.039 \\
\hline 14. CMC messages are impersonal. (Social Presence, \#4) & 98 & 3.21 & .933 \\
\hline $\begin{array}{l}\text { 15. CMC permits the building of trust relationships. (Social } \\
\text { Presence, \#15) }\end{array}$ & 98 & 3.21 & .955 \\
\hline $\begin{array}{l}\text { 16. It is unlikely that someone might obtain personal } \\
\text { information about you from the CMC messages. } \\
\text { (Social Presence, \#13) }\end{array}$ & 98 & 3.17 & 1.055 \\
\hline $\begin{array}{l}\text { 17. CMC allows me to build more caring social } \\
\text { relationship with others. (Social Presence, \#12) }\end{array}$ & 98 & 3.07 & .997 \\
\hline
\end{tabular}

In Table 4, the highest-ranked items seemed to indicate that students saw computer-mediated communication as a social experience and that they felt comfortable using a computer as a way to communicate. This is important, because comfort with computer-mediated communication is a vital component of blended learning. An equally surprising finding was that two of the lowestranked items dealt with whether computer-mediated communication helped to build trust and caring relationships. These low rankings might have been because discussion forums in the learningmanagement system are not as dynamic as some of the current social media tools like Facebook. Still, it is strange that respondents did not see online communication as being useful for building relationships although they did see it as a social experience. 


\section{Correlational Analysis}

The goal of the research questions was to investigate relationships between the three constructs of satisfaction, collaboration, and social presence, as well as to investigate any relationships between the demographic data and each of the constructs. Based on the research results, the study's four hypotheses, identified earlier, were explored using the Pearson product-moment correlation coefficient or Pearson's r.

\section{Null Hypothesis 1}

Table 5 shows the results of analyzing the correlation between the constructs of perceived social presence and reported course satisfaction. Using Pearson's $r$, there was a significant, moderate, positive correlation at $\mathrm{p}=.000(\mathrm{r}=.541$, significant at the 0.05 level $)$. We can determine that the correlation is positive since the Pearson correlation coefficient falls between 0 and 1 .

Table 5: Correlation between Perceived Social Presence and Reported Course Satisfaction

\begin{tabular}{lc}
\hline Measure & Statistic \\
\hline Pearson Correlation & $.541^{* *}$ \\
Sig. (2-tailed) & .000 \\
$\mathrm{R}^{2}$ & .293 \\
$\mathrm{~N}$ & 98 \\
\hline *** Correlation is significant at the 0.01 level (2-tailed). &
\end{tabular}

Thus, the first null hypothesis $(\mathrm{H} 1)$ is rejected since there is a significant, moderate, positive correlation between course satisfaction and social presence. As can be discerned from the resulting coefficient of determination, $29 \%$ of the variability in satisfaction can be accounted for by variability in social presence, with $71 \%$ of the variability being attributed to other unknown factors.

\section{Null Hypothesis 2}

Table 6 shows the results of analyzing the relationship between perceived collaboration and reported course satisfaction. Using Pearson's $r$, there was a significant high, positive correlation at $\mathrm{p}=.000(\mathrm{r}=.750$, significant at the 0.05 level $)$.

Table 6: Correlation between Perceived Collaboration and Reported Course Satisfaction

\begin{tabular}{lc}
\hline Measure & Statistic \\
\hline Pearson Correlation & $.750^{* * *}$ \\
Sig. (2-tailed) & .000 \\
$\mathrm{R}^{2}$ & .563 \\
$\mathrm{~N}$ & 98 \\
\hline
\end{tabular}

** Correlation is significant at the 0.01 level (2-tailed).

The second null hypothesis $(\mathrm{H} 2)$ is rejected since there is a significant high, positive correlation between course satisfaction and collaboration. Fifty-six percent of the variability in satisfaction can be accounted for by variability in perceived collaboration, with $44 \%$ of the variability being attributed to other unknown factors. 


\section{Null Hypothesis 3}

Table 7 shows the results of analyzing the relationship between perceived collaboration and perceived social presence using Pearson's $r$. The results indicate that there was a significant moderate positive correlation at $\mathrm{p}=.000(\mathrm{r}=.586$, significant at the 0.05 level $)$

Table 7: Correlation between Perceived Collaborative Leaming and Perceived Social Presence

\begin{tabular}{lc}
\hline Measure & Statistic \\
\hline Pearson Correlation & $.586^{* *}$ \\
Sig. (2-tailed) & .000 \\
$\mathrm{R}^{2}$ & .343 \\
$\mathrm{~N}$ & 98 \\
\hline
\end{tabular}

** Correlation is significant at the 0.01 level (2-tailed).

The third null hypothesis (H3) is rejected since there is a significant, moderate correlation between collaboration and social presence. Thirty-four percent of the variability in collaboration can be accounted for by variability in perceived social presence, with $66 \%$ of the variability being attributed to other unknown factors.

\section{Null Hypothesis 4}

The final hypothesis dealt with each of the demographic items and looked at any relationships they might have with the three constructs of perceived collaboration, perceived social presence, and satisfaction. This determined if a characteristic such as age, for example, had a statistical relationship with a construct such as course satisfaction. Although there were no major findings from the results of the study for $\mathrm{H} 4$, there was at least one item that stood out: the relationship between Latinos and social presence.

It was decided not to use a correlation coefficient to measure ethnicity because it was determined that it was a nominal variable and that it might be more appropriate to analyze it with a separate statistical method that will be discussed shortly. The results of the analysis of the relationships

Table 8: Relationships between Three Main Variables and Demographic Variables

\begin{tabular}{ccccc}
\hline Variable & Gender & Age & $\begin{array}{c}\text { Computer } \\
\text { Expertise }\end{array}$ & $\begin{array}{c}\text { \# of Distance } \\
\text { Courses } \\
\text { Taken }\end{array}$ \\
\hline Satisfaction & -.120 & $.220^{*}$ & .013 & .020 \\
Correlation & .238 & .030 & .902 & .842 \\
Sig. (2-tailed) & .014 & .05 & .0002 & .0004 \\
$\mathrm{R}^{2}$ & 98 & 98 & 98 & 98 \\
$\mathrm{~N}$ & & & & \\
Collaboration & -.146 & $.235^{*}$ & -.055 & .018 \\
Correlation & .150 & .020 & .590 & .858 \\
Sig. (2-tailed) & .021 & .055 & .003 & .0003 \\
$\mathrm{R}^{2}$ & 98 & 98 & 98 & 98 \\
$\mathrm{~N}$ & & & & -.006 \\
Social Presence & .014 & .080 & .178 & .956 \\
Correlation & .889 & .431 & .079 & .00004 \\
Sig. (2-tailed) & .0002 & .006 & .032 & 98 \\
$\mathrm{R}^{2}$ & 98 & 98 & 98 & \\
N & & & &
\end{tabular}


between gender, age, experience with computers, and previous number of distance education courses taken appear in Table 8.

Of the items measured in Table 8, only two relationships were significant. They were age with satisfaction and age with collaboration. Both had a low correlation which was positive, but the coefficient of determination for both was approximately .05, meaning only $5 \%$ of the variation in each of the variables could be accountable in the relationship, with $95 \%$ being due to unknown factors. Thus, while we technically cannot reject $\mathrm{H} 4$, for all practical purposes there were no relationships between these five demographic items and the three constructs that appeared to be worth mentioning or exploring further.

We decided not to look at a correlation between ethnicity as a whole and the three constructs, since ethnicity cannot be ranked. So the percentage, or frequency, of the number of participants in each group was reviewed. Looking at the descriptive statistics on the breakdown of ethnicity, we determined that the samples in most of the ethnic groups (with the exception of Latinos and Caucasians) were not large enough for analysis. We determined that we could analyze the selfidentified Latino and Caucasian participants in the study using the Mann-Whitney U test. The results are reported in Tables 9 and 10.

Table 9: Mann-Whitney U Test Ranks for Latino and Caucasian Participants for each Construct

\begin{tabular}{llll}
\hline Variable & N & Mean Rank & Sum of Ranks \\
\hline $\begin{array}{l}\text { Satisfaction } \\
\quad \text { Caucasian }\end{array}$ & 71 & & \\
$\quad$ Latino & 14 & 42.13 & 2991.50 \\
Collaboration & & 47.39 & 663.50 \\
$\quad$ Caucasian & 71 & 42.56 & 3022.00 \\
$\quad$ Latino & 14 & 45.21 & 633.00 \\
$\begin{array}{l}\text { Social Presence } \\
\quad \text { Caucasian }\end{array}$ & 71 & 40.18 & \\
$\quad$ Latino & 14 & 57.32 & 2852.50 \\
\hline
\end{tabular}

Table 9 shows the differences in the mean rank scores of each construct for the Latino and Caucasian students. The Mann-Whitney $U$ test is a non-parametric test that is useful for determining if the mean of two groups are different from each other and is an alternative to the parametric two-sample t-test. While the mean rank scores were slightly higher for the Latino participants across the board, the Latino mean rank for the social presence variable stood out over the others. However it did not provide any conclusive results. Table 10 provides more information on whether any of these differences were significant or not.

\begin{tabular}{llll}
\multicolumn{4}{l}{ Table 10: Test Statistics Grouped on the Latino Ethnicity Variable } \\
\hline Measure & Satisfaction & Collaboration & Social Presence \\
\hline & & & \\
Mann-Whitney U & 435.500 & 466.000 & 296.500 \\
Wilcoxon W & 2991.500 & 3022.000 & 2852.500 \\
z & -.729 & -.368 & -2.378 \\
$\begin{array}{l}\text { Asymp. Sig. (2- } \\
\text { tailed) }\end{array}$ & .466 & .713 & .017 \\
\hline
\end{tabular}


Table 10 shows that the variables for satisfaction and collaboration were not significant in their relationship with the Latino ethnic group. However, there is enough evidence to conclude that there is a difference in the mean ranks of the two ethnic groups in relationship to social presence. A significantly higher score by the Latino participants for perceived social presence appears to have been identified by the study, thus for Latino participants, we fail to reject $\mathrm{H} 4$ only in one specific situation: There is a relationship between Latino participants and a higher score in perceived social presence. Thus, the fourth null hypothesis (H4) is retained, and there is no correlation overall between the demographic variables (excluding ethnicity) and the three constructs.

\section{Discussion}

The findings of this study generally reflected expected outcomes and were similar to those of So $\&$ Brush (2008), who used the same instrument as we did in this study. However there were some unexpected results, which will be discussed below.

\section{Limitations}

This study was limited to a small rural campus located in an economically depressed section of the desert Southwest, so its findings may not be widely transferable to other communities whose members are more privileged with a variety of options for access to technology. Also, the campus is part of a college system that is not known for being a leader in technology integration or for providing the latest technology to its students. But the college does provide all of the essential elements required for a blended classroom.

The study limits its focus to three constructs: the two independent variables of perceived collaborative learning and social presence, and the dependent variable of self-reported student satisfaction with a blended course. It then examines the relationship between them. There is likely a much richer set of factors influencing student behavior and satisfaction, so this study is a preliminary, limited look at a very small set of constructs in a very dynamic learning situation. The instrument used to measure the constructs of collaborative learning, social presence, and student satisfaction may also be somewhat dated in light of the evolving fields of collaboration theory, Community of Inquiry theory, and blended learning theory.

Because the study focuses on correlation between variables, it will not prove causality. Similarly, finding a correlation between social presence or collaborative learning and student satisfaction will not allow us to state that these two variables predict student satisfaction.

\section{Conclusions from the Findings}

The finding of a moderate, positive relationship between social presence and student satisfaction mirrors other research suggesting a relationship between social presence and student satisfaction in online learning and blended learning (Gunawardena, 1995; Gunawardena \& Zittle, 1997; Jusoff \& Khodabandelou, 2009; Kang \& Kang, 2008; Liu et al., 2007; Richardson \& Swan, 2003; Tu, 2002; Tu \& McIsaac, 2002).

The two constructs of perceived collaboration and student satisfaction appeared to be highly related. This finding also mirrors research that suggests a relationship between collaboration and student satisfaction in online learning and blended-learning environments (Conrad \& Donaldson, 2004; Ferguson \& DeFelice, 2010; Garrison \& Vaughan, 2007; Jung et al., 2002; Nummenmaa \& Nummenmaa, 2008; Palloff \& Pratt, 2007; So \& Brush, 2008).

It is interesting that the relationship appeared to be much stronger between collaboration and student satisfaction than it appeared to be between social presence and student satisfaction, which is not necessarily what we expected due to the perception that collaborative activities can elicit 
negative reactions in some learners (Barkley, Cross, \& Major, 2004; Kirschner, Sweller, \& Clark, 2006).

The study confirmed that there appears to be a link between rising levels of perceived collaboration and rising levels of perceived social presence. While collaboration and social presence are theoretically independent variables that affect the dependent variable of self-reported student course satisfaction, there does appear to be a moderate relationship between the amount of perceived collaboration in a blended course and the amount of perceived social presence in a blended course. This should not be surprising since research has suggested that interactivity is an essential component of social presence ( $\mathrm{Tu}, 2002)$, and we can safely state that interactivity is increased as a result of collaborative activities. It is important to note, however, that interactivity and collaboration is not the same thing. Vesely, Bloom, and Sherlock (2007) defined collaboration as members of a community interacting to achieve a common learning goal. Other researchers have suggested that while social presence may not cause collaboration, it can affect the attitudes of participants about collaborating on a particular task (Kehrwald, 2007; Weinel et al., 2011; Wise, Chang, Duffy, \& del Valle, 2004). Rourke et al., (2001) and Rovai (2002) said they believe that social presence is also important in the development of a community of learners.

With the exception of a relationship between Latinos and higher self-reported perceptions of social presence, the study did not find a significant correlation between any of the demographic variables and the three constructs that were measured. This appears to be somewhat in-line with previous research that did not show any correlation between student satisfaction and student background characteristics such as age, gender, grade level, and computer expertise (Kitchen \& McDougall, 1999; Yaverbaum \& Ocker, 1998).

The finding that suggested a possibly higher rate of perceived social presence for Latino students than for Caucasian students is intriguing, though it is difficult to draw any hard conclusions since there were only 14 participants in the group of self-identified Latino students. We found this to be very interesting because while no study could be identified that specifically dealt with connections between social presence and Latinos/Hispanics, it is our suspicion that there may be cultural characteristics that might cause Latinos to perceive more social presence than their Caucasian counterparts, or to actually create it as a result of the dynamics of their culture.

While there is as yet no strong evidence, this may be the first study to suggest a higher relationship between Latinos/Hispanics and perceived social presence in blended learning. This could be a very important finding and a very beneficial future direction to take this research as the Latino/Hispanic population continues to increase in the United States and there is a sustained focus on ways to help Latino/Hispanic students succeed in learning environments like blended learning.

If this finding of an increased importance of social presence for a specific cultural group can be repeated with a larger sample, then we might be able to explore whether there are significant design issues that could enhance student completion when designing blended courses for populations that are dominated by one or two cultural groups. It also opens the door to the possibility that there may be all sorts of culture-related factors that blended-course designers should be aware of when creating a blended course for a targeted cultural group (Asunka, 2008; Hall \& Herrington, 2010; Jusoff \& Khodabandelou, 2009, Teng, 2005; Tu, 2001; Yen \& Tu, 2011; Yildiz, 2009).

The finding that no significant relationships existed between any of the other demographic variables and the three constructs may also be important because it suggests that social presence and collaboration equally correlate positively to course satisfaction in blended learning, regardless of variations in demographic variables such as gender, age, or computer expertise. 
One major conclusion that can be drawn from this study is to confirm that there does indeed appear to be a strong link between the amount of social presence and collaborative activities that a student perceives in a blended course and that student's self-reported satisfaction in the course. The other major conclusion that can be drawn from this study is that blended learning is an attractive instructional approach that holds promise for increasing student satisfaction and engagement, which should lead to increased course completion and program retention.

\section{Implications}

This study has several implications for educators, instructional designers, administrators, and policy makers. While we cannot draw any implications based on causality in this study, we can say that it appears that blended learning may indeed be a suitable approach for community colleges, based on the high levels of self-reported student satisfaction. It suggests that the use of blended learning should be encouraged by policy makers. It also appears that if student satisfaction is one goal of an institution or community-college system, then policy makers should encourage educational programs that feature collaborative activities and social presence in blended learning.

Data from this study can be used to suggest that blended learning which features collaboration and social presence can help institutions create better programs and support services that may lead to more effective learning environments. The evolution of these highly-effective, blendedlearning environments would happen through iterative cycles of implementation, followed by student evaluations, assessment, action research, and program reviews. As new research clarifies the value of the three constructs of social presence, collaboration, and satisfaction, as well as possibly additional constructs, it should help institutions and educators to create environments that assist students with developing the skills and aptitudes necessary to successfully complete a blended course.

One recommendation, then, is to not only offer blended learning, but also to build more effective blended courses using constantly improving technologies and learning-centered instructional methodologies (Liu et al. 2009). Blended-learning courses might include a variety of learning tools such as real-time virtual/collaboration software, self-paced learning materials, and social media; in addition to face-to-face (f2f) sessions in a classroom or other meeting area.

We also recommend that instruments similar to the CLSS Questionnaire be included in blendedlearning programs to support the use of data-driven decision-making and learning analytics in learning-centered environments. Learning analytics will play an increasingly important role in education as administrators and teachers begin to use technology and blended-learning approaches to personalize education for every student — not just students who are struggling.

One particularly promising strategy might be to focus on networked learning and object-oriented sociality within the blended environment (Cetina, 2001; Conole et al., 2008; Engeström, 2005). The theory of object-oriented sociality maintains that successful social networks aren't really centered on relationships or connections, but rather on the value held by learners for certain social objects. Rogers and Lea (2005) echo a similar idea when they state that in group collaboration, social identity - rather than interpersonal bonds - is the basis upon which social presence is built. The practical implication for this line of thought is that blended learning should attempt to build social networks around social objects that hold value and interest for the intended audience. The more interest a social object or idea holds for a group of learners, the more that group may experience increased social presence and collaboration.

Additionally, Liu et al. (2007) and Horton (2011) suggested that learners can be motivated to collaborate and stay engaged in a course by incorporating techniques such as setting clear expectations, requiring commitment, making online courses fun and interesting, providing encouraging feedback, building a learning community, and intervening early with unmotivated learners. 
Kehrwald (2007) asserted that in order to build these connections of collaboration and social presence, an online facilitator must build a strong presence in the course, the presence-building tasks should be included in early course activities, supportive activities should be included for novice online learners, and activities for interpersonal interaction should be required rather than suggested.

\section{Further Research}

Because our study focused on a relatively new instructional approach, more research is needed on blended learning - possibly including research on the combination of self-directed/independent and collaborative activities. While self-directed/independent activities weren't explored in this study, they should be contrasted with collaborative activities to see how each correlates to student satisfaction. Also, as the use of blended learning begins to grow in high schools, similar research might be pursued at the secondary level.

This study would likely have yielded a much fuller perspective if qualitative data had been included and the study had a mixed-method research design. Further research should include qualitative research so that we can begin to properly interpret the quantitative data and the interesting trends that we have seen in this study.

There is also not a great deal of social-presence research with Hispanic/Latino students or other specific cultural groups. This should be an area that is explored to see how collaboration and social presence might improve learning opportunities for various cultural groups. Further research might be conducted on whether blended learning improves the success rate of particular cultural groups of students when appropriate collaborative and social presence activities are promoted.

Finally, further research is warranted to determine if the constructs explored in this study go beyond a positive correlation with student satisfaction in blended learning and can be identified as predicting student satisfaction. To further this research, a brief overview of this study was presented at an international conference in order to get feedback and disseminate its principal concepts and initial findings (Sorden \& Ramirez, 2012).

\section{Summary}

Although this study did not compare student satisfaction or completion rates of blended learning with the same metrics in face-to-face or online environments, it does ultimately suggest that blended learning is a viable alternative approach to these two traditional approaches in community colleges. Many administrators, instructors, and instructional designers do not know how to approach blended-learning from an instructional-design perspective and simply view it as a division between face-to-face and online learning spaces. This will undoubtedly improve as more people experiment with blended learning and conduct research that is focused on this approach.

Beyond determining whether blended learning is successful as an instructional approach, part of this blended-learning research agenda will be to determine which characteristics make blendedlearning designs more successful in respect to student satisfaction, completion rates, and performance. This study demonstrated that there is a relationship between the three constructs of perceived collaboration, perceived social presence, and self-reported student satisfaction in blendedlearning courses. Its main significance is to show that these constructs are important for blendedlearning design and should be promoted in learning environments. In addition to these three constructs, there may be many more constructs which promote successful learning environments that will surface in future studies.

While the study focused on a small sample at one community college, it invites further research into whether similar results can be found at other community colleges around the country and 
whether other factors can be shown to have a relationship with student satisfaction and, ultimately, student-completion rates. The focus on blended-learning methods will likely increase as community colleges are pressured to improve completion rates and prove that their programs are effective in preparing students for the workforce and for transfer to four-year universities.

\section{References}

Albrecht, B. (2006). Enriching student experience through blended learning. Research Bulletin, 12, EDUCAUSE Center for Applied Research. Retrieved from http://net.educause.edu/ir/library/pdf/ERB0612.pdf

Asunka, S. (2008). Online learning in higher education in sub-Saharan Africa: Ghanaian university students' experiences and perceptions. The International Review of Research in Open and Distance Learning, 9(3), 1-23.

Bandura, A. (1985). Social foundations of thought and action: A social cognitive theory. Upper Saddle River, NJ: Prentice-Hall.

Barkley, E. F., Cross, K. P., \& Major, C. H. (2004) Collaborative learning techniques: A handbook for college faculty. Hoboken, N.J.: John Wiley \& Sons/Jossey-Bass.

Cetina, K. K. (2001). Objectual practice. In T. R. Schatzki, K. K. Cetina, \& E. von Savigny (Eds.), The practice turn in contemporary theory (pp.175-188). Abignon, Oxon, UK: Taylor \& Francis Group Ltd./Routledge.

Clusky, G. R., Jr., Hodges, C. W., \& Smith, S. (2006). The impact of online quizzing on student success in an introductory financial accounting class. Journal of College Teaching \& Learning, 3(7), 13-18.

Conole, G., Culver, J., Weller, M., Williams, P., Cross, S., Clark, P., \& Brasher, A.. (2008). Cloudworks: Social networking for learning design. In Hello! Where are you in the landscape of educational technology? Proceedings ASCILITE Melbourne 2008.

Conrad, R. M., \& Donaldson, J. A. (2004). Engaging the online learner: Activities and resources for creative instruction. San Francisco: John Wiley \& Sons/Jossey-Bass.

Dommel, H. P. (2005). The challenges of ambient collaboration. Proceedings of the Richard Tapia celebration of diversity in computing conference (pp. 10-13). Albuquerque, NM.

Engeström, J. (2005, April 13). Why some social network services work and others don't — or: the case for object centered sociality (blog posting). Retrieved from http://www.zengestrom.com/blog/2005/04/why_some_social.html

Ferguson, J. M., \& DeFelice, A. E. (2010). Length of online course and student satisfaction, perceived learning, and academic performance. The International Review of Research in Open and Distance Learning, 11(2), 73-84.

Garrison, D. R. (2009). Communities of inquiry in online learning. In P. L. Rogers, G. A. Berg, J. V. Boettcher, C. Howard, L. Justice, \& K. D. Shenk (Eds.), Encyclopedia of distance learning (2nd ed.) (pp. 352-355). Hershey, PA: IGI Global.

Garrison, D. R., \& Vaughan, N. D. (2007). Blended learning in higher education: Framework, principles, and guidelines. San Francisco: John Wiley \& Sons/Jossey-Bass.

Gunawardena, C. N. (1995). Social presence theory and implications for interaction and collaborative learning in computer conferences. International Journal of Educational Telecommunications. 1(2), 147-166.

Gunawardena, C. N., \& Zittle, F. J. (1997). Social presence as a predictor of satisfaction within a computermediated conferencing environment. American Journal of Distance Education, 11(3), 8-26.

Hall, A., \& Herrington, J. (2010). The development of social presence in online Arabic learning communities. Australasian Journal of Educational Technology, 26(7), 1012-1027. 
Homer, B. D., Plass, J. L., \& Blake, L. (2008). The effects of video on cognitive load and social presence in multimedia-learning. Computers in Human Behavior, 24(3), 786-797.

Horton, W. (2011) e-Learning by Design (2nd ed.). Hoboken, NJ: John Wiley and Sons/Pfeiffer.

Jarvela, S., \& Jarvenoja, H. (2011). Socially constructed self-regulated learning and motivation regulation in collaborative learning groups. Teachers College Record, 113(2), 350-374.

Jeong, H., \& Chi, M. T. H. (2007). Knowledge convergence during collaborative learning. Instructional Science, 35, 287-315.

Jung, I, Choi, S., Lim, C., \& Leem, J. (2002). Effects of different types of interaction on learning achievement, satisfaction, and participation in web-based instruction. Innovations in Education and Teaching International, 39(2), 153-162.

Jusoff, K., \& Khodabandelou, R. (2009). Preliminary study on the role of social presence in blendedlearning environment in higher education. International Education Studies, 2(4), 79-83.

Kang, M., \& Kang, J. (2008). Investigating the relationships of social presence, satisfaction, and learning achievement in the blended-learning environment. In J. Luca \& E. Weippl (Eds.), Proceedings of World Conference on Educational Multimedia, Hypermedia, and Telecommunications 2008 (pp. 717720). Chesapeake, VA: AACE.

Kehrwald, B. (2007). The ties that bind: Social presence, relations, and productive collaboration in online learning environments. In ICT: Providing choices for learners and learning. Proceedings ASCILITE Singapore 2007. Retrieved from http://www.ascilite.org.au/conferences/singapore07/procs/kehrwald.pdf

Kirschner, P. A., Sweller, J., \& Clark, R. E. (2006). Why minimal guidance during instruction does not work: An analysis of the failure of constructivist, discovery, problem-based, experiential, and inquirybased teaching. Educational Psychologist, 41(2), 75-86.

Kitchen, D., \& McDougall, D. (1999). Collaborative learning on the internet. Journal of Educational Technology Systems, 27(3), 245-258.

LaPointe, D. K., \& Gunawardena, C. N. (2004). Developing, testing and refining of a model to understand the relationship between peer interaction and learning outcomes in computer-mediated conferencing. Distance Education, 25(1), 83-106.

Liu, S., Gomez, J., Khan, B., \& Yen, C-J. (2007). Toward a learner-oriented community college online course dropout framework. International Journal on E-Learning, 6(4), 519-542.

Liu, S. Y., Gomez, J., \& Yen, C-J. (2009). Community college online course retention and final grade: Predictability of social presence. Journal of Interactive Online Learning, 8(2), 165-182.

Martin, B. L., \& Reigeluth, C. M. (1999). Affective education and the affective domain: Implications for instructional-design theories and models. In C. M. Reigeluth (Ed.), Instructional-design theories and models: A new paradigm of instructional theory (Vol. 2, pp. 485-509). Mahwah, NJ: Lawrence Erlbaum Associates.

Martin, O., \& Trigwell, K. (2005). Can 'blended learning' be redeemed? E-Learning and Digital Media, 2(1), 17-26.

Means, B., Toyama, Y., Murphy. R., Bakia, M., \& Jones, K. (2009). Evaluation of evidence-based practices in online learning: A meta-analysis and review of online-learning studies. Washington, D.C.: U.S. Department of Education.

Nummenmaa, M., \& Nummenmaa, L. (2008). University students' emotions, interests, and activities and a web-based learning environment. The British Journal of Educational Psychology, 78(Pt1), 163-178.

Osguthorpe, R. T., \& Graham, C. R. (2003). Blended learning environments: Definitions and directions. Quarterly Review of Distance Education, 4(3), 227-233.

Palloff, R. M., \& Pratt, K. (2007). Online learning communities in perspective. In R. Luppicini (Ed.), Online learning communities (pp. 3-16). Charlotte, NC: Information Age Publishing. 
Resta, P., \& Laferrière, T. (2007). Technology in support of collaborative learning. Educational Psychology Review, 19(1), 65-83.

Richardson, J. C., \& Swan, K. (2003). Examining social presence in online courses in relation to students' perceived learning and satisfaction. Journal of Asynchronous Learning Networks, 7(1), 68-88.

Rogers, P., \& Lea, M. (2005). Social presence in distributed group environments: The role of social identity. Behaviour \& Information Technology, 24(2), 151-158.

Roschelle, J. (1992). Learning by collaborating: Convergent conceptual change. The Journal of the Learning Sciences 2(3), 235-276.

Rourke, L., Anderson, T., Garrison, D. R., \& Archer, W. (2001). Assessing social presence in asynchronous text-based computer conferencing. Journal of Distance Education, 14, 50-71.

Rovai, A. (2002). Building a sense of community at a distance. International Review of Research in Open and Distance Learning, 3(1), 1-16. Retrieved from http://www.irrodl.org/index.php/irrodl/article/view/79/152

So, H-J., \& Brush, T. A. (2008). Student perceptions of collaborative learning, social presence, and satisfaction in a blended-learning environment: Relationships and critical factors. Computers \& Education, 51(1), 318-336.

Sorden, S. D., \& Ramirez, J. L. (2012). Collaborative learning, social presence and student satisfaction in a blended learning environment. Proceedings of 2012 IEEE 12th International Conference on Advanced Learning Technologies (pp.129-133). Rome: ICALT2012.

Stahl, G., Koschmann, T., \& Suthers, D. D. (2006). Computer-supported collaborative learning. In R. K. Sawyer (Ed.), Cambridge handbook of the learning sciences (pp. 409-426). Cambridge, UK: Cambridge University Press.

Stein, D. (2004). Student satisfaction depends on course structure. Online Classroom, Feb.: 4-5.

Teng, Y. (2005). An examination of social presence in online learning through the eyes of native and nonnative English speakers. State University of New York at Albany. Retrieved from ProQuest Dissertations and Theses. (Order No. 3181793)

$\mathrm{Tu}, \mathrm{C}-\mathrm{H}$. (1999). Reconstructing the social learning theory: Social presence theory in online learning. Proceedings of WebNet World Conference on the WWW and Internet 1999, 1082-1087. Chesapeake, VA:AACE.

Tu, C-H. (2001). How Chinese perceive social presence: An examination of interaction in online learning environment. Educational Media International, 38(1), 45-60.

$\mathrm{Tu}, \mathrm{C}-\mathrm{H}$. (2002). The measurement of social presence in an online learning environment. International Journal on E-Learning, 1(2), 34-45.

$\mathrm{Tu}, \mathrm{C}-\mathrm{H}$. (2004). Online collaborative learning communities: Twenty-one designs to building an online collaborative learning community. Engelwood, CO: Libraries Unlimited.

Tu, C-H., \& Corry, M. (2003). Building active online interaction via a collaborative learning community. Computers in the Schools, 20(3), 51-59.

Tu, C-H., \& McIsaac, M. (2002). The relationship of social presence and interaction in online classes. American Journal of Distance Education. 16(3), 131-150.

Vesely, P., Bloom, L., \& Sherlock, J. (2007). Key elements of building online community: Comparing faculty and student perceptions. Journal of Online Learning and Teaching, 3(3), 234-246. Retrieved from http://jolt.merlot.org/vol3no3/vesely.htm

Weinel, M., Bannert, M., Zumbach, J., Malzahn, N., \& Hoppe, H. (2011). A closer look on social presence as a causing factor in computer-mediated collaboration. Computers in Human Behavior, 27(1), 513521.

Wenger, E. (1999). Communities of practice: Learning, meaning, and identity. Cambridge, UK: Cambridge University Press. 
Wise, A., Chang, J., Duffy, T., del Valle, R. (2004). The effects of teacher social presence on student satisfaction, engagement, and learning. Journal of Educational Computing Research 31(3), 247-271.

Yaverbaum, G. J., \& Ocker, R. J. (1998). Problem solving in the virtual classroom: A study of student perceptions related to collaborative learning techniques. Paper presented at the WebNet 98 World conference of the WWW, Internet and Intranet, Orlando, FL.

Yen, C-J. \& Tu, C-H. (2011). A multiple-group confirmatory factor analysis of the scores for online social presence: Do they measure the same thing across cultural groups? Journal of Educational Computing Research, 44(2), 219-242.

Yildiz, S. (2009). Social presence in the web-based classroom: Implications for intercultural communication. Journal of Studies in International Education. 13(1), 46-65.

\section{Biographies}

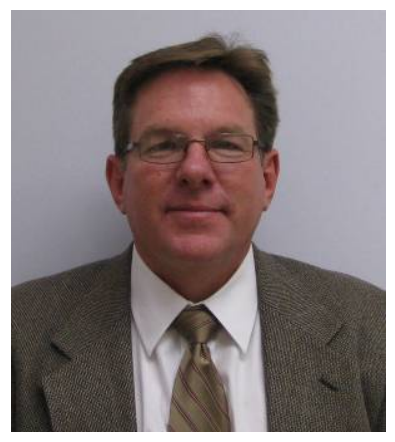

Dr. Stephen D. Sorden has a doctorate in Educational Leadership with an emphasis in Instructional Technologies, as well as a M.Ed. in Educational Technology. He currently serves as the Director of Career and Technical Education for the Chinle Unified School District in the center of the Navajo Nation, where he is focused on school improvement, technology in education, and coordinating dual enrollment programs with regional community colleges. His research interests include teaching and learning with technology, using data for school improvement, and technology adoption/diffusion of innovations in schools.

Prior to returning to his passion of K-12 education where he began his career as a computer teacher and principal, he served as the Director of the Center for Teaching and Learning at Embry-Riddle Aeronautical University, Academic Chair for a ground campus and the distance education campus at Mohave Community College, and the Manager of Learning and Professional Development for Information Technology Services at Northern Arizona University. He continues to teach courses as an adjunct and is currently working on a project to create a blended course on Navajo Government for high school students who are interested in pursuing the Chief Manuelito scholarship.

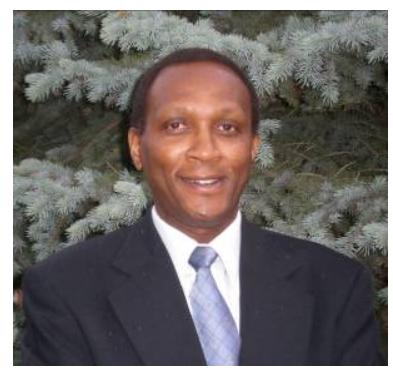

Dr. Ishmael I. Munene is an associate professor in the College of Education at Northern Arizona University. Ishmael I. Munene is an associate professor of educational research, higher education and foundations in the Department of Educational Leadership, College of Education at Northern Arizona University. He obtained his PhD in Higher Education Administration and Policy studies at the State University of New York at Albany, in the Department of Education Administration and Policy Studies. He also holds M.Ed in Comparative and International Education and a B.Ed in English and Literature from Kenyatta University in Kenya.

Munene's research interests center on African higher education, private higher education, higher education governance as well as foreign aid and Africa's educational development. He has researched and published widely in these areas, in addition to giving numerous academic presentations. His doctoral work focused on Kenya's higher education as it relates to issues of equity and merit in the admission of students. 